Agr. Biol. Chem., 38 (5), 1005 1013, 1974

\title{
Role of Tyrosine Residues in Interactions between Casein Components
}

\author{
Masaaki YoshiKawa, Etsuro Sugrmoto and Hideo Chiba \\ Department of Food Science and Technology, Faculty of Agriculture, \\ Kyoto University, Kyoto \\ Received November 26, 1973
}

\begin{abstract}
It was indicated from ultraviolet difference spectra and ultracentrifugal experiments that associations occurred between two casein components $\left(\alpha_{5}\right.$ - and $\kappa$-caseins, $\beta$ - and $\kappa$-caseins and $\alpha_{\mathrm{s}}$ - and $\beta$-caseins) at lower $\mathrm{CaCl}_{2}$ concentrations $(2 \sim 3 \mathrm{~mm})$ and that aromatic amino acid residues participated in the associations. Chemical modification studies with 2-hydroxy-5nitrobenzylbromide indicated that tryptophane residues of each casein component were not essential for these associations. It was also demonstrated by nitration of tyrosine residues with tetranitromethane that tyrosine residues of $\kappa$-casein were essential for $a_{\mathrm{s}} \cdot \kappa^{-}$ association and for $\beta \cdot \kappa$-association and that tyrosine residues of $\alpha_{\mathrm{s}}$-casein were important to $\alpha_{\mathrm{s}} \cdot \beta$-association.

Interactions between casein components were also studied at higher $\mathrm{CaCl}_{2}$ concentration $(10 \mathrm{~mm})$ which is enough for micelle formation. It was found that tyrosine residues of $k$ casein played an important role for the stabilization of $\alpha_{\mathrm{s}^{-}}$and $\beta$-caseins. Properties of the nitrated- $\beta$-casein were almost the same as that of the native $\beta$-casein except the absorption spectrum. $u_{s} \cdot \beta$-Interaction in the presence of $10 \mathrm{mM} \mathrm{CaCl}$ was investigated by use of the nitrated- $\beta$-casein instead of the native $\beta$-casein. It was proved that $\alpha_{\mathrm{s}}$-casein was stabilized by the nitrated- $\beta$-casein and that precipitation of the nitrated- $\beta$-casein increased in the presence of $a_{\mathrm{s}}$-casein.

The mechanism of interactions between casein components at higher $\mathrm{CaCl}_{2}$ concentration $(10 \mathrm{mM})$ are discussed in connection with the associations at lower $\mathrm{CaCl}_{2}$ concentrations $(2 \sim$ $3 \mathrm{mM})$.
\end{abstract}

In order to elucidate mechanism of the casein micelle formation, studies on interactions between casein components are important. It was found by Waugh et al. ${ }^{11}$ that $\alpha_{\mathrm{s}}$-casein was stabilized by $\kappa$-casein from precipitation in the presence of $\mathrm{CaCl}_{2}$. This interaction is understood to be the most fundamental step of the casein micelle formation. The association of $\alpha_{\mathrm{s}}$ - and $\kappa$-caseins was also observed in the absence of $\mathrm{CaCl}_{2}$ and have been studied by many workers. ${ }^{2 \sim 6)} \quad \alpha_{s} \cdot \beta$-Interaction ${ }^{7 \sim 9)}$ and $\beta \cdot \kappa$-interaction ${ }^{8 /}$ have been reported and these interactions are also considered to be important for the casein micelle formation. However, the knowledges on these interactions are limited.

Ultraviolet difference spectra were obtained in our laboratory by mixing $\alpha_{\mathrm{s}}$ - and $\kappa$-caseins, $\beta$ - and $\kappa$-caseins and $\alpha_{\mathrm{s}}$ - and $\beta$-caseins. These facts suggest that the associations occur betwe- en these pairs of casein components and that aromatic amino acid residues participate in the associations. The participation of tyrosine residues of $\kappa$-casein in $\alpha_{\mathrm{s}} \cdot \kappa$-interaction was reported in previous paper. ${ }^{5,6)}$

In this paper, the interactions between casein components ( $\alpha_{s}$ - and $\kappa$-caseins, $\beta$ - and $\kappa$-caseins and $\alpha_{s}$ and $\beta$-caseins) were investigated at two different concentration levels of $\mathrm{CaCl}_{2}$ with chemical modification of aromatic amino acid residues.

\section{MATERIALS AND METHODS}

Preparation of casein components. $\alpha_{\mathrm{s}^{-}}$and $\beta$ Caseins were prepared from individual Holstein cow by the methods of Zittle et al.11,12) and Hipp et al.,13) respectively. $\pi$-Casein was prepared by the method of Zittle et al. ${ }^{11,12)}$ with minor modification. Acid casein (wet weight: $350 \mathrm{~g}$ ) was dissolved in 1 liter of $6.6 \mathrm{M}$ urea. After the addition of 2 liter of water and $200 \mathrm{ml}$ 
of $7 \mathrm{~N} \mathrm{H}_{2} \mathrm{SO}_{4}$ the solution was allowed to stand for $2 \mathrm{hr}$ at $25^{\circ} \mathrm{C}$. The resulting precipitate was removed by centrifugation. The supernatant was subjected to ammonium sulfate fractionation and the fraction precipitated at $0.5 \sim 1.0 \mathrm{M}$ was collected. Further purifications were performed according to the Zittle's procedure. Protein concentrations were determined from optical density. The $E_{1 \mathrm{~cm}, 280 \mathrm{~nm}}^{1 \%}$ values used were 10.0 for $\alpha_{S^{-}}$and $\kappa$-caseins and 4.7 for $\beta$ casein..$^{3,9}$ Values of 27,000, 24,000 and 20,000 were used for monomer molecular weights of $\alpha_{\mathrm{s}^{-}}$and $\beta$ and $\kappa$-caseins, respectively. $14 \sim 16$ )

Chemicals. 2-Hydroxy-5-nitrobenzylbromide was purchased from Seikagaku Co. Tetranitromethane (Extra-pure grade) and other reagents (Guaranteed reagent grade) were purchased from Nakarai Chemicals Co.

Instruments. Ultraviolet difference spectra of casein components were recorded with Hitachi double beam spectrophotometer model-124 equipped with a constant temperature cell holder. The output of the spectrophotometer (full range: $10 \mathrm{mV}$ ) was connected to the input of Hitachi automatic recorder model QPD 34 (full range: $1 \mathrm{mV}$ ). Thus ten fold expanded spectra were obtained.

Sedimentation experiments were performed with Beckman model $\mathrm{E}$ analytical ultracentrifuge equipped with RTIC control unit.

$\mathrm{CaCl}_{2}$ Concentrations. Calcium ion is indispensable for the casein micelle formation. Micelle or precipitate is not formed at $2 \sim 3 \mathrm{mM} \mathrm{CaCl}$. Molecular interactions between casein components were studied under these conditions and these interactions are called associations in this paper. Casein micelle is formed at $10 \mathrm{mM} \mathrm{CaCl}_{2}$. Interactions between casein components were also studied under these conditions. These interactions are called the stabilization and the coprecipitation.

Chemical modification of casein components. Nitration of casein components was performed with tetranitromethane as described previously. ${ }^{5,17,18)}$ Numbers of modified tyrosine residues were calculated from the absorbance at $381 \mathrm{~nm}(\varepsilon=2200)$.

Chemical modification of tryptophane residues of casein components by 2-hydroxy-5-nitrobenzylbromide was performed in $6 \mathrm{M}$ urea at $\mathrm{pH} 3$. 2-Hydroxy-5nitrobenzylbromide dissolved in a minimum volume of acetone was added to the solution of each casein component $(5 \mathrm{mg} / \mathrm{ml})$ in a $50: 1$ molar ratio to the concentration of tryptophane residues. As the reaction proceeded, $1 \mathrm{~N} \mathrm{NaOH}$ was added in order to keep pH 3. The reaction was stopped after $1 \mathrm{hr}$ by passing the reaction mixture through Sephadex G-25 column equilibrated with $6 \mathrm{M}$ urea containing $1 \mathrm{~mm}$
$\mathrm{HCl}$, and the protein fraction was neutralized. The protein solution was dialyzed against water and lyophilized. Numbers of modified tryptophane residues were calculated from the absorbance at $410 \mathrm{~nm}$ $(\varepsilon=18,000){ }^{19}$

Precipitation of casein components. Precipitations of $\alpha_{\mathrm{s}^{-}}, \beta$-caseins and their modified samples were tested as follows. The standard reaction mixture contained $2.5 \mathrm{mg}$ of protein, $10 \mu$ moles of imidazole buffer, $\mathrm{pH} 7.1$ and $10 \mu$ moles of $\mathrm{CaCl}_{2}$ in a volume of $1.0 \mathrm{ml}$. After the precincubation of protein solution for $20 \mathrm{~min}$ at $35^{\circ} \mathrm{C}$, the precipitate was made by quick addition of $10 \mathrm{~mm} \mathrm{CaCl}$. The suspension was incubated for $1 \mathrm{hr}$ and the precipitate was removed by centrifugation at $3000 \mathrm{rpm}$, for $10 \mathrm{sec}$. The supernatant thus obtained was diluted with $0.05 \mathrm{M}$ potassium citrate and the protein concentration was measured by the absorbance at $280 \mathrm{~nm}$.

Stabilization of $\alpha_{\mathrm{B}^{-}}$or $\beta$-casein by $\kappa$-casein. Stabilization of $\alpha_{\mathrm{S}^{-}}$or $\beta$-casein by $\kappa$-casein was tested under the same conditions as those of precipitation experiments except that reaction mixture contained $0.25 \mathrm{mg} \kappa$-casein. The amount of $\alpha_{\mathrm{s}^{-}}$or $\beta$-casein in the supernatant was calculated by subtracting the amount of $\kappa$-casein added from the total protein in the supernatant.

Interaction of $\alpha_{\mathrm{s}^{-}}$and nitrated- $\beta$-caseins in the presence of $10 \mathrm{mM} \mathrm{CaCl}_{2}$. The interaction of $\alpha_{\mathrm{s}^{-}}$and the nitrated- $\beta$-caseins was tested as follows. The reaction mixture contained $2.5 \mathrm{mg}$ of $\alpha_{\mathrm{s}}$-casein, $2.5 \mathrm{mg}$ of the nitrated- $\beta$-casein, $10 \mu$ moles of imidazole buffer, pH 7.1 and $10 \mu$ moles of $\mathrm{CaCl}_{2}$ in a total volume of $1.0 \mathrm{ml}$. After the solution containing $\alpha_{\mathrm{s}^{-}}$and the nitrated- $\beta$-caseins was preincubated for $20 \mathrm{~min}, \mathrm{CaCl}_{2}$ was added to the solution at temperatures indicated in Fig. 5. At the same temperature, the mixture was incubated for $1 \mathrm{hr}$ and centrifuged at $3000 \mathrm{rpm}$, for $10 \mathrm{sec}$. The amount of the nitrated- $\beta$-casein in the supernatant was determined from the absorbance at $381 \mathrm{~nm}$. From this result, the contribution of the nitrated- $\beta$-casein to the absorbance of the supernatant at $280 \mathrm{~nm}$ was calculated. Therefore, the amount of $a_{\mathrm{s}}$-casein in the supernatant can be obtained from the absorbance at $280 \mathrm{~nm}$.

\section{RESULTS}

\section{Ultraviolet difference spectra}

Changes of the ultraviolet absorption spectra caused by mixing two casein components were studied in the presence of $2 \mathrm{mM} \mathrm{CaCl}_{2}$ at $20^{\circ} \mathrm{C}$. As shown in Fig. 1, red shifts in the ultraviolet absorption spectra were observed in every 
cases, although each difference spectrum had a different intensity. Difference of molar extinction coefficient at $286 \mathrm{~nm}$ were calculated to be 2000 per $\kappa$-casein monomer (curve I),

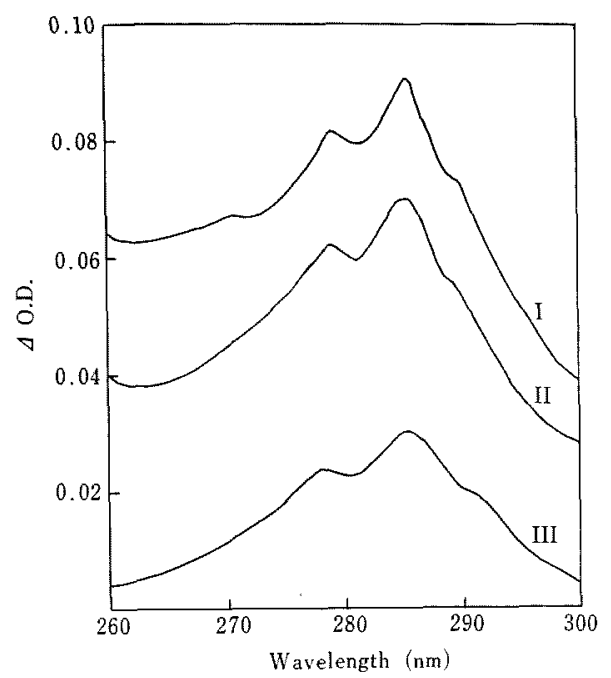

FIG. 1. Difference Spectra Produced by Mixing Two Casein Components.

Casein components were dissolved in $10 \mathrm{~mm}$ imidazole buffer, $\mathrm{pH} 7.1$, containing $2 \mathrm{mM} \mathrm{CaCl}$. In the case of curve I ( $\alpha_{8}$-casein $+\kappa$-casein), each compartment (light path: $4.5 \mathrm{~mm}$ ) of reference tandem cell was filled with solutions of $a_{\mathrm{s}}$-casein $(2 \mathrm{mg} / \mathrm{ml})$ and $\kappa$ casein $(2 \mathrm{mg} / \mathrm{ml})$, respectively, and both compartments of sample tandem cell were filled with a mixture of $a_{\mathrm{s}}$-casein and $\kappa$-casein (concentration of each component: $1 \mathrm{mg} / \mathrm{ml})$. Curve II $(\beta$-casein $+\kappa$ casein) and curve III ( $\alpha_{\mathrm{s}}$-casein $+\beta$-casein) were obtained by the same procedure as described above.

1600 per $\kappa$-casein monomer (curve II) and 500 per $a_{\mathrm{s}}$-casein monomer (curve III). These spectra suggest that casein components interact under these conditions and that there occurred some changes in the environments of aromatic amino acid residues of both or one of the two components. The main peak at $286 \mathrm{~nm}$ and the small peak or shoulder at $293 \mathrm{~nm}$ in the difference spectra suggest that the contribution of tryptophane residues to the difference spectra is relatively small compared with that of tyrosine residues in every cases.

\section{Association between casein components}

Associations between casein components were studied by ultracentrifugal experiments. Although associations between casein components were hardly observed in $10 \mathrm{~mm}$ imidazole buffer, $\mathrm{pH} 7.1$, associations were promoted by the addition of $\mathrm{CaCl}_{2}$. Partial associations were observed at $20^{\circ} \mathrm{C}$ in the same buffer containing $2 \mathrm{mM} \mathrm{CaCl}_{2}$. Almost complete associations were observed at $35^{\circ} \mathrm{C}$ in the presence of $3 \mathrm{mM} \mathrm{CaCl}$. Therefore, studies on associations were performed at $35^{\circ} \mathrm{C}$ in $10 \mathrm{~mm}$ imidazole buffer, $\mathrm{pH} 7.1$, containing $3 \mathrm{mM} \mathrm{CaCl}_{2}$ (Fig. 2).

i) $\alpha_{\mathrm{s}} \cdot \kappa$-Association. The mixture of $\alpha_{\mathrm{s}}$ casein (5.2 S) and $\kappa$-casein (19.4 S) gave a single peak with a sedimentation coefficient of $11.8 \mathrm{~S}$. This means that there occurred an association between both components. $a_{\mathrm{s}} \cdot \kappa$-Association seems to be accompanied by the dissociation of $\kappa$-casein into smaller unit.

ii) $\beta \cdot \kappa$-Association. The mixture of $\beta$ and $\kappa$-caseins gave a single peak with a sedimentation coefficient, $13.1 \mathrm{~S}$ which is smaller than that of both components (15.7 S and 19.4 S). $\beta \cdot \kappa$-Association might be accompanied by the dissociation of both components into smaller units.

iii) $\alpha_{\mathrm{s}} \cdot \beta$-Association. The mixture of $\alpha_{\mathrm{s}}$ and $\beta$-caseins gave a single peak with a similar sedimentation coefficient value $(5.1 \mathrm{~S})$ to that of $\alpha_{\mathrm{s}}$-casein $(5.2 \mathrm{~S})$. On the basis of the area of the $5.1 \mathrm{~S}$ peak and of the absence of the peak corresponding to $\beta$-casein, the $5.1 \mathrm{~S}$ peak is considered to be a complex of $\alpha_{s^{-}}$and $\beta$ caseins.

Sedimentation coefficient of modified casein components

Sedimentation patterns of modified casein components were investigated at $35^{\circ} \mathrm{C}$ in $10 \mathrm{~mm}$ imidazole buffer, pH 7.1, containing $3 \mathrm{~mm}$ $\mathrm{CaCl}_{2}$. Sedimentation coefficient of the nitrated casein components was different from that of the native components. The sedimentation coefficient of $\alpha_{\mathrm{s}}$-casein decreased from $5.2 \mathrm{~S}$ to $4.2 \mathrm{~S}$, and that of $\kappa$-casein from $19.4 \mathrm{~S}$ to $11.5 \mathrm{~S}$ after the nitration of tyrosine residues. 


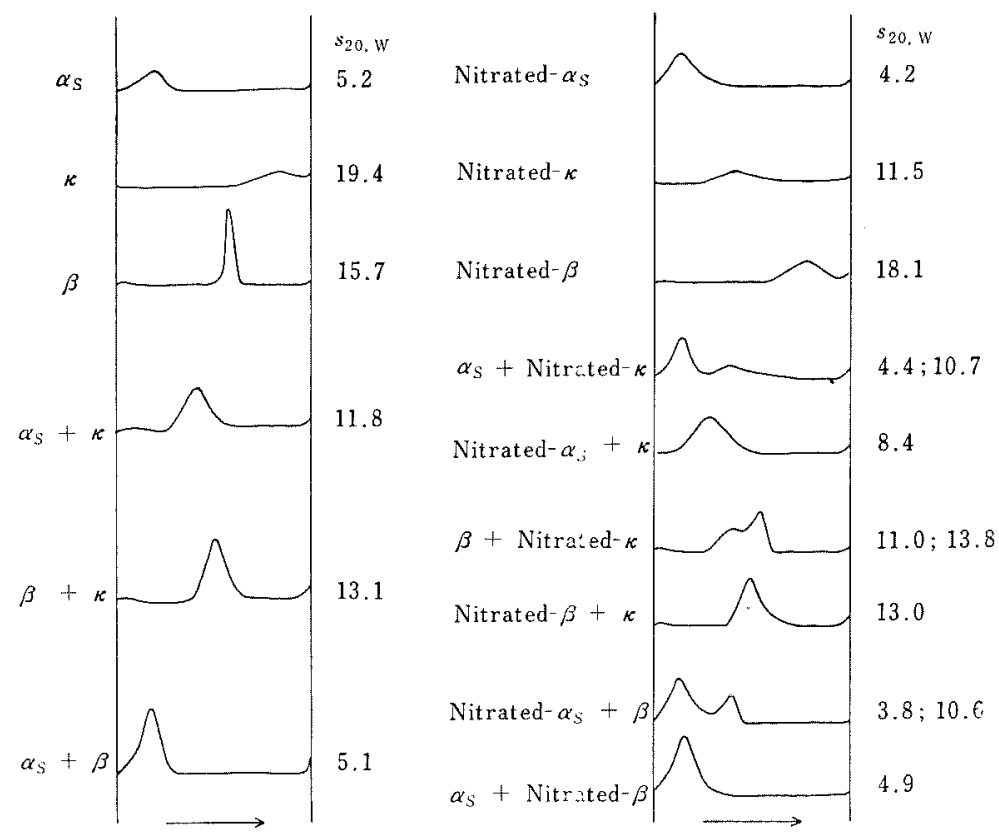

FIG. 2. Sedimentation Patterns.

Each component $(4 \mathrm{mg} / \mathrm{ml})$ was dissolved in $10 \mathrm{~mm}$ imidazole buffer, $\mathrm{pH} 7.1$ containing $3 \mathrm{~mm}$ $\mathrm{CaCl}_{2}$. Centrifugations were performed at $35^{\circ} \mathrm{C}, 60,000 \mathrm{rpm}$. Photographs were taken $18 \pm 1 \mathrm{~min}$ after reaching maximum speed. Numbers of modified tyrosine residues per mole of each casein component were as follows; nitrated- $\alpha_{\mathrm{S}}$-casein: 8.5 , nitrated- $\kappa$-casein: 7.1 , nitrated- $\beta$-casein: 3.8 .

These decreases may result from reduction of $\mathrm{Ca}^{2+}$-dependent self-association of these casein components. In the case of $\beta$-casein, the sedimentation coefficient increased from $15.7 \mathrm{~S}$ to $18.1 \mathrm{~S}$ and the sedimentation pattern was poly-disperse after the nitration of tyrosine residues. The native $\beta$-casein was completely dissociated at $4^{\circ} \mathrm{C}^{20\}} \quad$ Dissociation of $\beta$-casein also occurred in the presence of $0.5 \% \mathrm{SDS}^{21}{ }^{21}$ The sedimentation pattern of the nitrated- $\beta$ casein was poly-disperse and its sedimentation coefficient was slightly larger than that of the native $\beta$-casein at $4^{\circ} \mathrm{C}$ or in the presence of $0.5 \%$ SDS. Therefore, these changes in sedimentation profiles induced by reaction with tetranitromethane may be derived from covallent cross-linking between $\beta$-casein molecules as observed in other proteins. ${ }^{22,23)}$

Sedimentation coefficient of individual casein components modified with 2-hydroxy-5-nitrobenzylbromide (HNB-caseins) were almost the same as the native components.
Effect of chemical modifications on the association between casein components

Associations between native and modified casein components were investigated in the presence of $3 \mathrm{mM} \mathrm{CaCl}$.

i) $\alpha_{\mathrm{s}} \cdot \kappa$-Association. The association of $\alpha_{\mathrm{s}}$-and the nitrated- $\kappa$-caseins was not observed. On the other hand, the association of $\kappa$ - and the nitrated- $a_{\mathrm{s}}$-caseins was observed, although the sedimentation coefficient of the complex was smaller than that of the native complex (Fig. 2). These results are similar to the facts observed in $10 \mathrm{~mm}$ imidazole buffer, $\mathrm{pH} 7.1$, containing $0.07 \mathrm{M} \mathrm{KCl}^{6}$ )

ii) $\beta \cdot \kappa$-Association. The association of $\beta$ - and $\kappa$-caseins was also inhibited by the nitration of tyrosine residues of $\kappa$-casein. Tyrosine residues of $\kappa$-casein seem to be essential for the association. The association of $\kappa^{-}$and the nitrated- $\beta$-caseins was almost intact and brought a formation of a complex 
with the same sedimentation coefficient value as that of the native complex of $\beta$-and $\kappa$-caseins (Fig. 2). Thus tyrosine residues of $\beta$-casein seem to be not essential for $\beta \cdot \kappa$-association.

iii) $\alpha_{\mathrm{s}} \cdot \beta$-Association. The nitrated- $\beta$-casein associated with $\alpha_{\mathrm{s}}$-casein and gave a complex. The sedimentation coefficient of the complex was almost the same as that of the native complex. The sedimentation pattern of the mixture of $\beta$ - and the nitrated- $\alpha_{\mathrm{s}}$-casein was complicated. In this case, the complex formation seems to be only partial. The $10.6 \mathrm{~S}$ peak may correspond to $\beta$-casein. The $3.8 \mathrm{~S}$ peak may be the complex and/or nitrated- $\alpha_{\mathrm{s}}$-casein. Discrepancy in the sedimentation coefficients of $\beta$-casein (15.7 S and 10.6 S) may be ascribed to the difference in the self-association at different concentrations of free $\beta$-casein (Fig. 2).

The associations of native and modified casein components of which tryptophane residues were almost completely modified with 2hydroxy-5-nitrobenzylbromide were intact in each combinations ( $\kappa$ - and HNB- $\alpha_{s}$-caseins, HNB- $\kappa$ - and $\alpha_{\mathrm{s}}$-caseins, $\beta$ - and HNB- $\kappa$-caseins, HNB- $\beta$ - and $\kappa$-caseins, $\alpha_{\mathrm{s}}$ - and HNB- $\beta$-caseins and HNB- $\alpha_{\mathrm{s}}$ - and $\beta$-caseins).

It was concluded that for the individual associations ( $\alpha_{\mathrm{s}}$ - and $\kappa$-caseins, $\beta$ - and $\kappa$-caseins and $\alpha_{\mathrm{s}}$ - and $\beta$-caseins) tyrosine residues of $\kappa$-, $\kappa$ - and $\alpha_{s}$-caseins play important roles, respectively. It is supposed that the ultraviolet difference spectra (Fig. 1) are caused by environmental changes of these essential tyrosine residues.

\section{Properties of modified casein components in the presence of $10 \mathrm{mM} \mathrm{CaCl}_{2}$}

The effects of chemical modifications on casein components were investigated in the presence of $10 \mathrm{mM} \mathrm{CaCl}_{2}$ which is enough for casein micelle formation. The properties of the HNB-casein components were essentially the same as that of the native casein components. The properties of the nitrated casein components were as follows.

i) Nitrated- $\kappa$-casein. The stabilizing ability of $\kappa$-casein against $\alpha_{\mathrm{s}}$ - or $\beta$-casein was tested at a weight ratio of 1:10. As shown in Fig. 3, the nitration of $\kappa$-casein resulted in the loss of stabilizing ability against $\beta$-casein as well as $\alpha_{\mathrm{s}}$-casein. Both stabilization (Fig. 3) and association (Fig. 2) were inhibited by the nitration of tyrosine residues of $\kappa$-casein. These facts suggest that $\alpha_{\mathrm{s}} \cdot \kappa$-association and $\beta \cdot \kappa$ association are prerequisite to the stabilization of $\alpha_{\mathrm{s}}$ - and $\beta$-caseins by $\kappa$-casein.

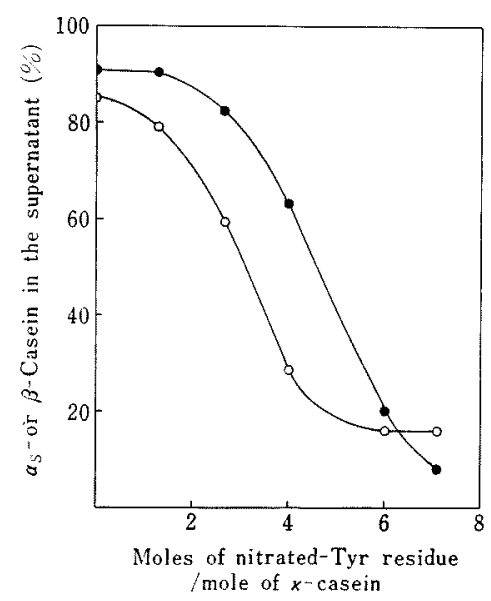

FIG. 3. Effect of Nitration on Stabilizing Ability of $\kappa$-Casein.

Stabilization was tested in $10 \mathrm{~mm}$ imidazole buffer, pH 7.1 containing $10 \mathrm{~mm} \mathrm{CaCl} 2$ at $35^{\circ} \mathrm{C}$. Protein concentrations were as follows; $\alpha_{\mathrm{s}}$-casein: $2.5 \mathrm{mg} / \mathrm{ml}$, $\beta$-casein: $2.5 \mathrm{mg} / \mathrm{ml}, \kappa$-casein: $0.25 \mathrm{mg} / \mathrm{ml}$.

$0, \alpha_{\mathrm{s}}$-casein; $0-0, \beta$-casein.

ii) Nitrated- $\alpha_{\mathrm{s}}$-casein. The native $\alpha_{\mathrm{s}}$-casein precipitated completely in $10 \mathrm{~mm}$ imidazole buffer, pH 7.1, containing $10 \mathrm{~mm} \mathrm{CaCl}_{2}$. When 4 among 8 tyrosine residues of $\alpha_{\mathrm{s}}$-casein were nitrated, the nitrated- $\alpha_{\mathrm{s}}$-casein did not precipitate under the same conditions as reported previously. ${ }^{6)}$ Therefore, the stabilization of the nitrated- $\alpha_{\mathrm{s}}$-casein by $\kappa$ - or $\beta$-casein could not be estimated.

iii) Nitrated- $\beta$-casein. The effect of nitration of tyrosine residues on the properties of $\beta$-casein was investigated. As shown in Fig. $4 \mathrm{~A}$ and $\mathrm{B}$, nitration of 3.8 tyrosine residues among 4 residues resulted in little alteration in the calcium-dependent precipitation of $\beta$ casein. This suggests that $\beta$-casein has a differ- 


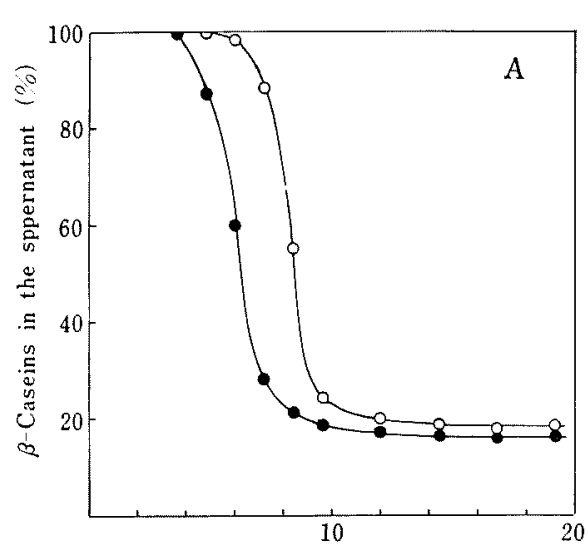

$\left[\mathrm{CaCl}_{2}\right](\mathrm{mH})$

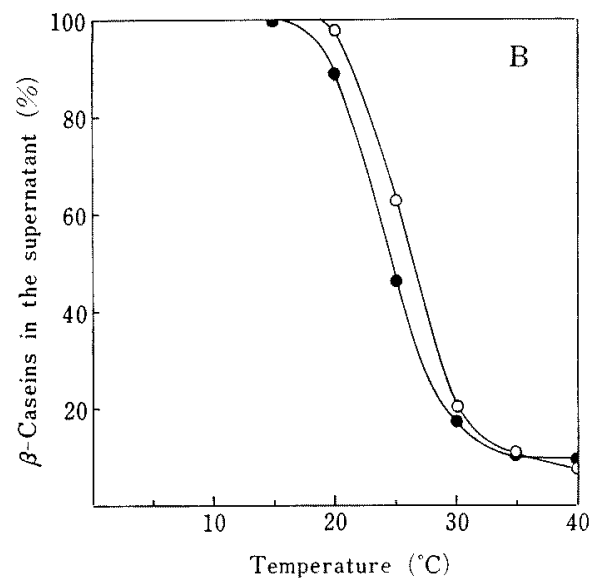

FIG. 4. Effect of Nitration on Solubility of $\beta$ Casein.

Concentrations of $\beta$-casein and nitrated- $\beta$-casein were $2.5 \mathrm{mg} / \mathrm{ml}$. Number of nitrated tyrosine residues was 3.8 per mole of $\beta$-casein. Experiment A was performed in $10 \mathrm{~mm}$ imidazole buffer, $\mathrm{pH} 7.1$, containing various concentrations of $\mathrm{CaCl}_{2}$ at $35^{\circ} \mathrm{C}$. Experiment $B$ was performed in the same buffer containing $10 \mathrm{~mm} \mathrm{CaCl}$ at various temperatures.

- $-\beta$-casein; $O-0$, nitrated- $\beta$-casein.

ent mechanism of calcium-dependent precipitation from that of $\alpha_{s}$-casein which does not precipitate after the nitration of tyrosine residues.

As shown in Table I, it was also found that the nitrated- $\beta$-casein as well as the native $\beta$ casein was stabilized by $\kappa$-casein. The nitrated $-\beta$-casein associated with $\alpha_{\mathrm{s}}$ - or $\kappa$-casein (Fig. 2 ). Therefore, the nitrated $-\beta$-casein seems to retain the properties of the native $\beta$-casein except for having absorbance in the visible region.
Table I. Stabilization of $\beta$ - Casein BY $\kappa$-CASEIN

Stabilization was tested in $10 \mathrm{~mm}$ imidazole buffer, pH 7.1, containing $10 \mathrm{~mm} \mathrm{CaCl}_{2}$ at $35^{\circ} \mathrm{C}$. Protein concentrations were as follows; $\beta$-casein: $2.5 \mathrm{mg} / \mathrm{ml}$, nitrated- $\beta$-casein: $2.5 \mathrm{mg} / \mathrm{ml}, \kappa$-casein: $0.25 \mathrm{mg} / \mathrm{ml}$.

\begin{tabular}{lc}
\hline & $\begin{array}{c}\beta \text { - or Nitrated- } \beta \text {-casein } \\
\text { in the supernatant }\end{array}$ \\
\hline$\beta$ & $12 \%$ \\
$\beta+\kappa$ & 86 \\
Nitrated- $\beta$ & 19 \\
Nitrated- $\beta+\kappa$ & 90 \\
\hline
\end{tabular}

The amount of this colored derivative of $\beta$ casein could be easily determined in a mixture with other components.

Interaction of $\alpha_{\mathrm{s}}$ - and nitrated- $\beta$-casein in the presence of $10 \mathrm{mM} \mathrm{CaCl}_{2}$

The interaction of $\alpha_{\mathrm{s}}$ - and the nitrated- $\beta$ caseins was investigated as a model of $\alpha_{\mathrm{s}} \cdot \beta$ interaction (Fig. 5A and B). Most of $\alpha_{s}$ casein precipitated in all temperature tested and the nitrated- $\beta$-casein was completely soluble below $20^{\circ} \mathrm{C}$ in the presence of $10 \mathrm{mM} \mathrm{CaCl}_{2}$. When equal amount of both components were mixed, solubility of $\alpha_{\mathrm{s}}$-casein was enhanced (stabilization) and that of the nitrated- $\beta$-casein decreased (coprecipitation). As shown in Fig. 5B, stabilization of $\alpha_{\mathrm{s}}$-casein by the nitrated- $\beta$-casein was maximum at $10^{\circ} \mathrm{C}$, and coprecipitation of the nitrated- $\beta$-casein with $\alpha_{\mathrm{s}}$-casein was maximum at $25^{\circ} \mathrm{C}$. The supernatant thus obtained was opalescent. Stabilization of $\alpha_{\mathrm{s}}$-casein by the nitrated- $\beta$-casein was tested in various weight ratio at $10^{\circ} \mathrm{C}$. Stabilization of $\alpha_{\mathrm{s}}$-casein increased with increasing amounts of the nitrated- $\beta$-casein (Fig. 6). Maximum stabilization of $\alpha_{s}$-casein appeared at a weight ratio near unity. The stabilizing ability of the nitrated- $\beta$-casein against $\alpha_{\mathrm{s}}$-casein was about $1 / 10$ compared with that of $\kappa$-casein. Coprecipitation of the nitrated- $\beta$-casein by $\alpha_{\mathrm{s}}$-casein was tested in various weight ratio at $20^{\circ} \mathrm{C}$. Coprecipitation of the nitrated- $\beta$-casein with $\alpha_{\mathrm{s}}$-casein exhibited its maximum value at a ratio of $1: 2$ (Fig. 7). It is interesting that this weight ratio is same to 


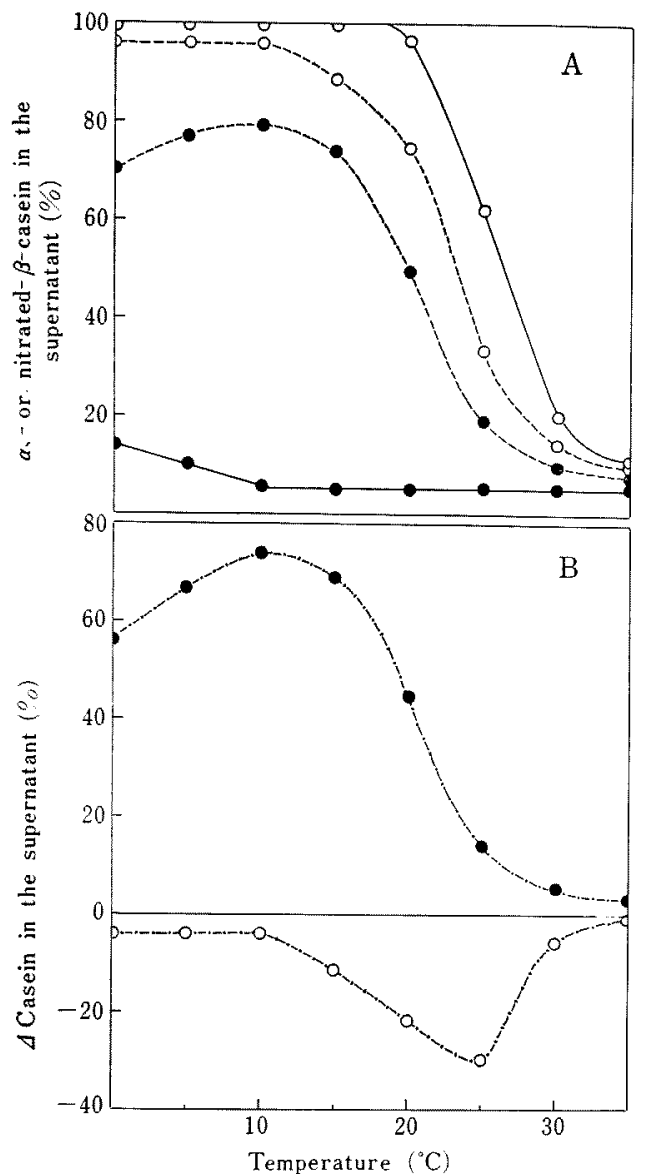

Fig. 5. Stabilization of $\alpha_{\mathrm{S}}$-Casein and Coprecipitation of Nitrated- $\beta$-Casein.

Solubility was tested in $10 \mathrm{~mm}$ imidazole buffer, $\mathrm{pH}$ 7.1 , containing $10 \mathrm{mM} \mathrm{CaCl}_{2}$ at various temperatures. Concentrations of $u_{s}$-casein and nitrated- $\beta$-casein were $2.5 \mathrm{mg} / \mathrm{ml}$. Number of nitrated tyrosine residues was 3.8 per mole of $\beta$-casein.

(A): Solubility of $\alpha_{\mathrm{s}}$-casein and nitrated- $\beta$-casein as a function of temperature.

- - $\alpha_{\mathrm{s}}$-casein; --.-,$\alpha_{\mathrm{s}}$-casein tested in a mixture of $\alpha_{\mathrm{s}}$-casein and nitrated- $\beta$-casein; $0-0$, nitrated- $\beta$ casein; $0--0$, nitrated- $\beta$-casein tested in a mixture of $\alpha_{\mathrm{s}}$-casein and nitrated- $\beta$-casein.

(B): Changes of solubilities $\alpha_{\mathrm{s}}$-casein and nitrated- $\beta$ casein caused by mixing of both components.

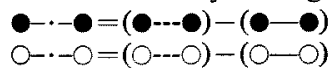

the ratio of $\beta$ - and $\alpha_{\mathrm{s}}$-caseins in milk.

\section{DISCUSSION}

From the experimental results, it was concluded that tyrosine residues were essential for

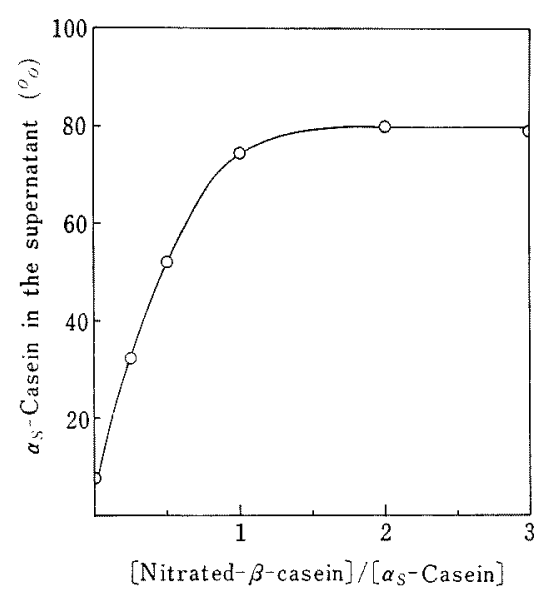

FIG. 6. Stabilization of $\alpha_{\mathrm{s}}$-Casein by Nitrated- $\beta$ Casein at $10^{\circ} \mathrm{C}$.

Stabilization was tested in $10 \mathrm{~mm}$ imidazole buffer, pH 7.1, containing $10 \mathrm{~mm} \mathrm{CaCl}$ at various weight ratio of both components. Concentration of $a_{\mathrm{s}^{-}}$ casein was $2.5 \mathrm{mg} / \mathrm{ml}$. Number of nitrated tyrosine residues was 3.8 per mole of $\beta$-casein.

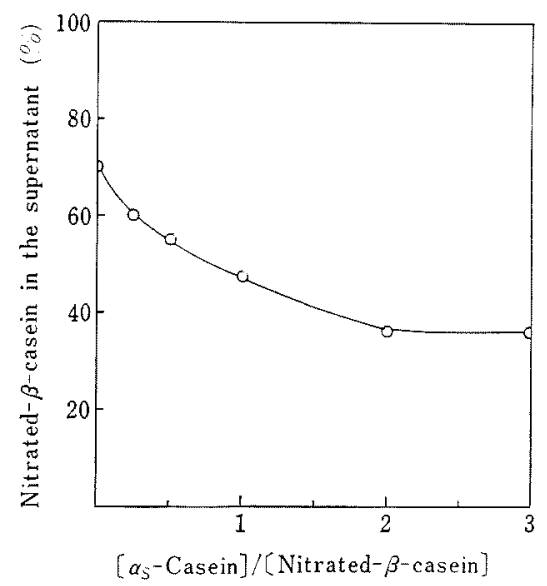

FIG. 7. Coprecipitation of Nitrated- $\beta$-Casein by $\alpha_{\mathrm{s}^{-}}$ Casein at $20^{\circ} \mathrm{C}$.

Solubility was tested in $10 \mathrm{~mm}$ imidazole buffer, $\mathrm{pH}$ 7.1 , containing $10 \mathrm{mM} \mathrm{CaCl}$ at various weight ratio of both components. Concentration of nitrated- $\beta$ casein was $2.5 \mathrm{mg} / \mathrm{ml}$. Number of nitrated tyrosine residues was 3.8 per mole of $\beta$-casein.

the association of casein components. It could be argued against our conclusion that the ultraviolet difference spectra (Fig. 1) was produced by the environmental changes of nonessential aromatic amino acid residues and that inhibition of the associations by chemical 
modification was due to changes in conformation or in net charges induced by chemical modification of non-essential tyrosine residues. However, both the difference spectra and the inhibition of association by chemical modification were observed in every combinations. Therefore, the essential role of tyrosine residues for respective associations seems to be valid as described in the results.

The essential role of tyrosine residues of $\kappa$ casein for $\alpha_{\mathrm{s}} \cdot \kappa$-interaction was indicated by chemical modification and other experiments in the previous paper. ${ }^{6}$ These results are not contradictory to the results of ultraviolet difference spectra in this paper.

It was also found that tyrosine residues of $\kappa$-casein were also essential for $\beta \cdot \kappa$-association and for the stabilization of $\beta$-casein by $\kappa$-casein.

All of tyrosine residues of $\kappa$-casein are located exclusively in para- $\kappa$ region. ${ }^{24,251}$ These facts suggest that para- $\kappa$ region of $\kappa$ casein molecules participates in $\beta \cdot \kappa$-interactions (association and stabilization) as well as in $\alpha_{\mathrm{s}} \cdot \kappa$-interactions. ${ }^{6,26 !}$

The stabilizing ability of $\kappa$-casein for $\beta$-casein was more sensitive to the nitration than for $\alpha_{\mathrm{s}}$-casein (Fig. 3). Peak in the difference spectra caused by $\beta \cdot \kappa$-association was smaller than that caused by $\alpha_{\mathrm{s}} \cdot \kappa$-association (Fig. 1 , peak I and II). These facts suggest that smaller number of tyrosine residues of $\kappa$-casein contribute to $\beta \cdot \kappa$-interaction compared with the case of $\alpha_{\mathrm{s}} \cdot \kappa$-interaction.

Properties of the nitrated- $\beta$-casein are as follows; 1) Manners of precipitation of the nitrated- $\beta$-casein under the various conditions are almost the same as those of the native $\beta$-casein (Fig. 3). 2) The nitrated- $\beta$-casein has a little larger sedimentation coefficient than that of the native $\beta$-casein (Fig. 1). 3) The nitrated$\beta$-casein associates with $\alpha_{\mathrm{s}}$ - or $\kappa$-casein in similar manners to the native $\beta$-casein. These complexes have the same sedimentation coefficient as those of the native components (Fig. 2). 4) The nitrated- $\beta$-casein, as well as the native $\beta$-casein, is stabilized by $\kappa$-casein in the presence of $10 \mathrm{mM} \mathrm{CaCl}_{2}$.

Thus the nitrated- $\beta$-casein seems to retain essentially identical properties to the native $\beta$-casein except for having a little larger sedimentation coefficient and absorbance in the visible region. In order to study quantitatively the $\alpha_{\mathrm{s}} \cdot \beta$-interaction at higher $\mathrm{CaCl}_{2}$ concentration, determination of the ratio $\alpha_{s^{-}}$and $\beta$ caseins in the supernatant or the precipitate is necessary. The determination of the ratio $\alpha_{\mathrm{s}^{-}}$ and $\beta$-caseins is difficult because of the similar chemical nature of the both casein components. The nitrated- $\beta$-casein has almost the same properties as the native $\beta$-casein as described above. Therefore, the interaction between $\alpha_{\mathrm{s}}$ - and the nitrated- $\beta$-caseins at higher $\mathrm{CaCl}_{2}$ concentration was studied as a model of $\alpha_{\mathrm{s}} \cdot \beta$-interaction. As shown in Fig. $5 \mathrm{~A}$, solubilities of $\alpha_{\mathrm{s}}$ and the nitrated- $\beta$-caseins were changed by the interaction of the both components. The amounts of stabilized $\alpha_{\mathrm{s}}$-casein and coprecipitated nitrated- $\beta$-casein changed markedly according to the temperature and showed their maxima at different temperatures. It is supposed that the contribution of hydrophobic binding forces at higher temperature alter the manner of the interaction between $\alpha_{\mathrm{s}}$ - and the nitrated- $\beta$ caseins. The coprecipitation of the nitrated$\beta$-casein by $\alpha_{\mathrm{s}}$-casein was maximum at $25^{\circ} \mathrm{C}$. However, this would not mean that the interaction between $\alpha_{s^{-}}$and the nitrated- $\beta$-caseins was weakened above this temperature. Almost all the nitrated- $\beta$-casein precipitated at elevated temperatures even in the absence of $\alpha_{\mathrm{s}}$-casein. The nitrated- $\beta$-casein to be coprecipitated by $\alpha_{\mathrm{s}}$-casein was left in a little amount in the supernatant. This fact may be the cause for observed decrease of the coprecipitation of the nitrated- $\beta$-casein by $\alpha_{\mathrm{s}}$-casein above $25^{\circ} \mathrm{C}$. This idea was supported by ultracentrifugal experiments. Dissociation of the complex between $\alpha_{\mathrm{s}}$ - and the nitrated- $\beta$-caseins was not observed above $25^{\circ} \mathrm{C}$ (Fig. 2).

Interaction between $\alpha_{\mathrm{s}^{-}}$and $\beta$-caseins was also studied by Waugh et al. They concluded that the comingled precipitate of $\alpha_{s}$ and $\beta$ caseins was a core of casein micelle. ${ }^{9)}$ Coprecipitation of nitrated- $\beta$-casein by $\alpha_{\mathrm{s}}$-casein may be correlated to the comingled precipitate described by Waugh et al. Stabilization of $\alpha_{\mathrm{s}}{ }^{-}$ 
casein by the nitrated- $\beta$-casein at lower temperature may correspond to the metastable colloid described qualitatively by Waugh. ${ }^{27}$

The possibility that the stabilization of $\alpha_{\mathrm{s}}$ casein by the nitrated- $\beta$-casein may result from contaminating $\kappa$-casein was excluded by the fact that the stabilizing ability of $\kappa$-casein against $\alpha_{\mathrm{s}}$-casein is lost by the nitration of tyrosine residues of $\kappa$-casein.

Data indicating that the interaction between $\alpha_{\mathrm{s}}$-and the native $\beta$-caseins are essentially the same as the interaction between $\alpha_{s^{-}}$and the nitrated- $\beta$-caseins have been obtained in this labolatory (unpublished data). It is an interesting problem why such a temperaturedependent interaction occur between $\alpha_{\mathrm{s}}$ - and $\beta$-caseins. Studies on the mechanism of $\alpha_{\mathrm{s}} \cdot \beta$ interaction is in progress.

\section{REFERENCES}

1) D. F. Waugh and P. H. von Hippel, J. Am. Chem. Soc., 78, 4576 (1956).

2) J. Garnier, J. Yon and G. Mocquot, Biochim. Biophys. Acta, 82, 481 (1964).

3) R. W. Noble and D. F. Waugh, J. Am. Chem. Soc., 2236, 2246 (1965).

4) R. Clarke and S. Nakai, Biochemistry, 10, 3353 (1971).

5) H. Chiba, K. Tatsumi, R. Sasaki and E. Sugimoto, Nippon Nogeikagaku Kaishi, 44, 364 (1970).

6) H. Chiba, K. Tatsumi, R. Sasaki and E. Sugimoto, ibid., 44, 376 (1970).

7) P. H. von Hippel and D. F. Waugh, J. Am. Chem.
Soc., 77, 4311 (1955).

8) T. A. J. Payens, Biochem. J., 108, 14 (1968).

9) D. F. Waugh, L. K. Creamer, C. W. Slattery and G. W. Dresner, Biochemistry, 9, 786 (1970).

10) C. A. Zittle and M. Walter, J. Dairy Sci, 46, 1189 (1963).

11) C. A. Zittle, J. Cerbulis, L. Pepper and E. S. Dellamonica, ibid., 42, 1897 (1959).

12) C. A. Zittle and J. H. Custer, ibid., 46, 1183 (1963).

13) N. J. Hipp, M. L. Groves, J. H. Custer and T. L. McMeekin, ibid., 35, 272 (1952).

14) P. Dreizen, R. W. Noble and D. F. Waugh, $J$. Am. Chem. Soc., 84, 4938 (1962).

15) R. F. Peterson, L. W. Nauman and D. F. Hamilton, J. Dairy Sci., 49, 601 (1966).

16) H. E. Swaisgood and J. R. Brunner, Biochem. Biophys. Res. Comm., 12, 148 (1963).

17) J. F. Riordan, M. Sokolovsky and B. L. Vallee, J. Am. Chem. Soc., 88, 4104 (1966).

18) J. F. Riordan, M. Sokolovsky and B. L. Vallee, Biochemistry, 5, 3582 (1966).

19) H. R. Morton and D. E. Koshland Jr.; J. Am. Chem. Soc., 87, 1126 (1965).

20) T. A. J. Payens and B.W. van Markwijk, Biochim. Biophys. Acta, 71, 517 (1963).

21) R. Niki, I. Kato and S. Arima, Milchwissenschaft, 26, 141 (1971).

22) R. J. Doyle, J. Bello and O. A. Roholt, Biochim. Biophys, Acta, 160, 274 (1968).

23) R. W. Boesel and F. H. Carpenter, Biochem. Biophys. Res. Comm., 38, 678 (1968).

24) E. B. Kalan and J. H. Woychik, J. Dairy Sci., 48, 1423 (1965).

25) J. C. Mercier, G. Brignon and B. RibadeauDumas, Eur. J. Biochem., 35, 222 (1973).

26) R. J. Hill and R. G. Wake, Nature, 221, 635 (1969).

27) D. F. Waugh, "Milk Proteins," Vol. II, Academic Press Inc., New York, N.Y., 1971, p. 37. 